\title{
STUDIES ON EPIDERMAL APPENDAGES FROM VEGETATIVE ORGANS AT EUPHORBIA SPECIES CULTIVATED IN BOTANICAL GARDEN IASSY
}

\author{
Camelia IFRIM $^{1}$ \\ 1 "Alexandru Ioan Cuza” University of Iassy, "Anastasie Fătu” Botanical Garden, \\ 7-9 Dumbrava Roşie street, Iassy-Romania \\ E-mail: camelia.ifrim@uaic.ro
}

\begin{abstract}
The Euphorbia genus is unitary by the presence of the characteristic inflorescence named cyathium, but presents a remarkable morphological diversity of aerial vegetative organs. Species that originated in the tropical zones, especially South-African ones stand out by the presence of some epidermal appendages little known (trichomes, spines, leaf scars). Of those, the spines are the most conspicuous and intriguing from a structural point of view; the botanical terminology used for describing their features is critically presented. The representatives of the Euphorbia genus cultivated in Botanical Garden Iassy greenhouses were morphologically analysed and a detailed description of epidermal appendages resulted, which is useful in clearing taxonomical aspects.
\end{abstract}

Key words: epidermal appendages, Euphorbia, leaf scar, spine shields, vegetative organs.

\section{Introduction}

The Euphorbia genus presents an impressive morphological variability, correlated with the huge number of comprised species (approx. 2000) and the diversity of their habitats. Already vast, the genus was enriched by the immersion of taxa from Monadenium, Pedilanthus and Synadenium genera [BRUYNS \& al. 2006; STEINMANN, 2003], determined by the last molecular genetic studies.

Characteristic for this genus is the presence of a particular inflorescence, named cyathium [BERRY \& al. 2016; BROWN \& al. 1925], which was intensively studied, morphologically and structurally. Quite frequently the inflorescence can't be seen at cultivated species, which originated from tropical and subtropical areas because of its lack of blooming. In this case the features of the aerial vegetative organs can be useful in identification, but in ecological, horticultural, pharmacological etc. studies as well. Anatomical and/or morphological studies on representatives of this genus are quite rare [ZAHRA \& al. 2014] and focused mostly on species originated from the northern hemisphere [GALEŞ \& TOMA, 2006; TALEBI, 2017]. The epidermal appendages are less studied at this genus, and sometimes these bear particular characteristics, rarely seen in the vegetal domain (especially at South African species).

The studied epidermal appendages from the vegetative organs are trichomes, spines and leaf scars.

The importance of the study of trichomes in resolving taxonomical [COURT, 2000] and ecological aspects is widely recognised, but in the case of the Euphorbia genus these studies are few and focused especially on herbaceous, non-succulent species [THAKUR \& PATIL, 2012; ZAHRA \& al. 2014]. 
The spines present at succulent species which originate from arid areas (especially South Africa) are structures which frequently cause confusions with cactuses, these two groups of plants being the best known examples of convergent evolution. Otherwise spurges are considered homologous of cactuses in African arid areas. The presence of the spines together with the stem's appearance are the reasons for these expression used in the description of spiny succulent spurges: cactus-like [GILBERT \& CARTER 1984; NEUWINGER 1996], cactiform [EVANS \& al. 2014; ARCO AGUILAR \& RODRÍGUEZ DELGADO, 2018]. The spines of the Euphorbia genus are different from those of cactuses (most of them are of stipelar origin and are developed on a specific structure named spine shields), and in comparison with them [DREZNER, 2017; GEBAUER \& al. 2016] are less studied (or not at all), structurally and functionally. About the Euphorbia genus's spines general aspects are known, which are applicable for all spinescent species and just a few papers remember their ecological role [RABESANDRATANA, 1984], without a subject focused analysis.

Probably the reduced frequency of information about spines (comparatively with those refering to cactuses' spines) can be the source of the inexplicable mistake of some botanists who mentioned that in the case of Euphorbia canariensis the leaves turned into spines [ÁLVAREZ ESCOBAR \& RODRÍGUEZ DELGADO, 2014]. This mistake is that much more regretable because it appeared in a paper that reached a great number of specialists from various domains (agriculture, cultural anthropology, biology, ecology, pharmacognosy, linguistics) comparatively with their valuable work [DIAZ HERNANDEZ \& RODRIGUEZ DELGADO, 1995] used strictly in botanical domain.

Leaf scars can't be considered epidermal appendages in the classical sense, but at some of the analyzed species these represent obvious characters, easy to analyze and always presented. They are mentioned in the description of some species in specialty literature [CARTER \& LEACH, 2001].

\section{Material and methods}

The studied material is represented by vegetative organs of 26 taxa from the Euphorbia genus belonging to the collection cultivated in greenhouses of "Anastasie Fătu" Botanical Garden Iassy.

The vegetal matter comes from species with ages between 30 and 40 years old $(E$. aphylla Brouss. ex Willd., E. canariensis L., E. grandicornis Goebel ex N. E. Br., E. grandidens Haw., E. ingens E. Mey ex Boiss., E. ramipressa Croizat, E. tirucalli L., E. trigona Mill.), between 15 and 20 years old (E. guentheri (Pax) Bruyns, E. myrsinites L.), between 10 and 12 years old (E. bicompacta Bruyns var. rubra (S. Carter) Bruyns, E. bubalina Boiss., E. caerulescens Haw., E. cotinifolia L., E. flanaganii N. E. Br., E. ferox Marloth, E. globosa (Haw.) Sims, E. lactea Haw., E. milii Des Moul., E. pulcherrima Willd. ex Klotzsch, E. stenoclada Baill., E. umbellata (Pax) Bruyns), and between 5 and 10 years old (E. leuconeura Boiss., E. pteroneura A. Berger, E. tithymaloides L.).

The number of items from each species varies: 1 (E. ingens, E. grandidens and $E$. stenoclada), 2 (E. bubalina, E. caerulescens, E. ferox, E. lactea, E. ramipressa), 3-15 (the rest of the species).

The study was focused on three types of epidermal appendages: spines, trichomes and foliar scars from vegetative aerial organs. 
In order to observe the spines and the leaf scars 20 spiny structures were analyzed, along with scars from the mature sections (at least 2 years old). In order to observe trichoms 20 leaves collected from species whose leaves last for at least a few months were analyzed. In the case of E. myrsinites, the aerial leaf stems last only for one vegetative season, dying in winter.

The information from specialty literature [BERRY \& al. 2016; CARTER, 2002; CARTER \& LEACH, 2001; CARTER \& RADCLIFFE-SMITH, 1988; CREMERS, 1978; JSTOR 2013; SWANEPOEL, 2013] was compiled with the observations realized with the help of an Optika stereo microscope (spines and leaf scars), and an Optika microscope (trichomes). The most relevant aspects have been photographed with a Canon A540 camera.

\section{Results and discussion}

The most obvious and interesting epidermal appendages at studied spurges are the spines. The succulent species of the Euphorbia genus from the arid areas of South Africa are considered homologous of the cacti in the American areas with similar weather conditions. In accordance with the theory of convergence evolution, spines are present as a result of adaptation to a harsh environment and often these two groups of plants are mistaken for each other. This confusion is facilitated as well by the fact that cultivated representatives of Euphorbia rarely bloom (ex. E. trigona, E. canariensis).

At the African species described in Flora capensis [BROWN \& al. 1925], the spines are of three types conform to their provenance:

1. the apex of the branches turned into a sharp spine (ex. E. stenoclada);

2. the peduncle of the inflorescence turned into a sharp spine (ex. E. ferox);

3. spines in pairs named "stipular spines", differently disposed towards leaf scars (ex. E. caerulescens).

BROWN (1925) come into notice that this last type of spines can't be considered stipules in the real sense of the word, but the term is used in specialty literature [CARTER, 2002] referring to the Euphorbia genus. The second type of spines is designed by DOREEN COURT (2000) as peduncular spines, meanwhile MAPAYA (2003) names them "inflorescence thorns because they are homologous with inflorescences" or their withered and retained central axes.

The characteristic structure on which the spines develop is most frequently named spine shields [CARTER \& LEACH, 2001]. In Flora of Tropical East Africa [BEENTJE \& CHEE, 2014] it is shown that this term is rarely used and it is defined as a "horny pad from which the spines stick out". In a precedent work [SCHMIDT \& al. 2002] this structure is identified by the term warty cushions, which appears in COATES PALGRAVE'S work (2013) as well, but apparently with a different signification. Spine shields are a defining character for African spiny succulent species and their features can be diagnosis characters.

DORSEY \& al. (2013) point that spine shields "typically bears two or four spiny outgrowths". These outgrowths are interpreted by CARTER (1994) as "a pair of spines and a pair of stipules modified as prickles". These prickles [CARTER \& LEACH, 2001] are named dorsal spines by MAPAYA or rudimentary spines by SWANEPOEL.

Secondary spines are named those which flank the floriferous eyes [CARTER \& LEACH, 2001].

The features of epidermal appendages from species of the Euphorbia genus collection cultivated at Botanical Garden Iassy are presented below: 
E. aphylla: leaf scars sparse, apparently punctiforme, approximately $0.2 \mathrm{~mm}$ diameter, whitish.

E. bicompacta var. rubra: leaf scars elliptical, reniform or semilunar, $1 \mathrm{~cm}$ apart, obvious especially due to light brown colour on green surface of the photosynthetic stem; 3$18 \mathrm{~mm}$ length, on old stem they are bigger due to increase in thickness.

E. bubalina: leaf scars semicircular to triangular, approximately $1.5 \mathrm{~mm}$ length, 1.5 $2 \mathrm{~cm}$ apart, disposed at apical end of tuberculate segments.

E. caerulescens: spine shields whitish-grey connected in a horny edge, on the most part of edges stem; spines in pair, 0.5-1.2 cm length, whitish with deep brown apex, straight or slightly curved, made an angle of 120 degrees.

E. canariensis (Plate I, D): spine shield almost circular or elliptical, decurent, approximately $3 \mathrm{~mm}$ diameter, approximately $1 \mathrm{~mm}$ apart, reddish-brown becomes soon light brown. Spines in pairs shining brown disposed throughout angles of stem, $\pm 4 \mathrm{~mm}$ length, horizontal spreading, making an angle of approximately 180 degrees, straight or "cow-horn" shaped, very sharp.

E. cotinifolia (Plate II, B): non-glandular trichomes unicellular cylindrical reddish on the upper side of the petiole of the young leaves, soon caducous.

E. ferox (Plate I, H): spines (modified peduncles) solitary or rarely 3, disposed along the 8 angles, mostly $3.8-7.6 \mathrm{~cm}$ apart, $1.3-3.2 \mathrm{~cm}$ length, stout, very rigid, woody, straight or variably curved and more or less horizontally spreading except the few at the apex, brown becoming grey.

E. flanaganii: leaf scars semicircular, whitish, at the apical end of the tuberculate segment from the lower part of the branches or on the tubercles of the central stem.

E. globosa (Haw.) Sims: leaf scars irregular-ovate or semicircular, approximately $0.5 \mathrm{~mm}$ length, on the apex of the tubercle.

E. grandicornis (Plate I, A): spine shields fusiform, grey or brownish joined in a continuous horny edge. Spines in pairs very stout, 15-70 $\mathrm{mm}$ long, 2-3 $\mathrm{mm}$ thick at the base, but reduced to c. $3 \mathrm{~mm}$ length at the constrictions of the branches, 2-3 cm apart, widely diverging at an angle of 160-180 ${ }^{\circ}$, grayish or pale brown, the apex darker and sharp; prickles minute, 1-2 mm length, below the spines; secondary spines on one side and the other of the flowering eyes, 1-2 mm long.

Leaf scars between the spines, semicircular to triangular

E. grandidens: on main stem spine shield obovate, isolated, $1.5-2.5 \mathrm{~cm}$ apart, $1.5-8$ mm length; spines pair, 2-9 mm length, black at the apex, rarely parallel, most frequent divergent (till 180 degree). On the terminal branches spine shields decurent transversely elliptic; spineless or with a pair of reduced spines, 1.5-2.5 mm length, $2.2 \mathrm{~cm}$ apart, divergent at an angle of 100 degrees, straight or cow-horn shaped; prickles minute, sometimes squamiform.

E. guentheri (Plate I, C): a cluster of 5 spines on each tubercle of the stem; 3 of them are disposed on a triangular shape, 1-2 mm length, solid, the central one reclined; the two other spines smaller ( $1 \mathrm{~mm}$ length). Leaf scars approx. $1 \mathrm{~mm}$, almost circular, above and bordered by spines.

E. ingens (Plate I, J, K,): Spine shields oval or obovate, 12-18 mm apart, 4-5 mm in diameter, extending $5 \mathrm{~mm}$ above to include the flowering eye. Spineless or with a pair of spines 2-5 mm length, straight, divergent at an angle of 120 degrees. Spines and spine shields 
are initially brown but soon becoming corky, rusty-brown and disintegrating or grey on old segment of the stem.

E. lactea: Spine shields light brown, decurrent, lanceolate, wider in medial zone, where are the spines, sometimes comprises flowering eyes on the upper part. Spines in pair, 2-6 mm length, divergent at an angle of 60 degrees, dark brown and very sharp at the apex, most of them down curved.

E. leuconeura (Plate II, C, D, I, J): cartilaginous stipules light brown or whitishgrey, divided in numerous bristles up to $5 \mathrm{~mm}$ length, joined and making a continuous edge.

Leaf scars linear to reniform, $1.5-2.5 \mathrm{~cm}$ apart; sometimes joined with branches' scars; obvious especially due to light brown colour on green surface of the photosynthetic stem.

E. milii (horticultural varieties) (Plate I, F, Plate II E, H): trichomes unicellular whitish on stem, petiole, base of leaf and lower half of spines, at the mature ones only in basal part. The most trichomes are simply, cylindrical, with acuminate or rounded apex; a few trichomes are clavate.

Spines in pairs (rarely 1 or 3 ) flanking the leaves or leaf scars, the pairs approximately parallel; spines 1-2 cm length, straight, grey with brown apex, very sharp, divergent at an angle of 45 degrees.

Leaf scars semicircular or reniform, approximately $2.5 \mathrm{~cm}$ length, gray.

E. myrsinites L.: leaf scars semilunar, approximately $3 \mathrm{~mm}$ length, light brown, alternate disposed and at an angle of 45 degree towards the stem.

E. pteroneura (Plate II, J): leaf scars semicircular or semilunar, 3-7 mm length, disposed on demarcation line of segments of the branches, $2-5 \mathrm{~cm}$ apart, alternate disposed.

E. pulcherrima (horticultural varieties): non-glandular trichomes multicellular uniseriate crisped, whitish, uniform disposed on lower side of leaf lamina, numerous; similar on upper side in lower third, on veins and edges of the lamina, otherwise rarely or absent.

E. ramipressa (Plate I, B, I): spine shields obovate (on old stem) or pentagonal, slightly decurent. Spines in pairs, darker at the apex, straight or curved (cow-horn shape), divergent at an angle of 120 degrees. Above the spines are two rudimentar prickles as a foliaceous squame, with approximately circular shape. Sometimes spine shields are reduced in dimension, the spines are very small or absent. On the old lignified stem, spine shields are more decurrent and sometimes joined in a subcontinuous series.

E. stenoclada (Plate I, G): on juvenile form of the plant terminal branches have the apex transformed in spine, brown, approximately $2 \mathrm{~mm}$ length.

E. tirucalli (Plate II, F): The extreme tips of young leafy branchlets sparsely tomentose with curled white hairs.

Foliar scar semicircular, light brown, approximately $1 \mathrm{~mm}$ length, perpendicular on the stem surface. Most often on one side and the other are stipular remnants, as two blackish squama.

E. tithymaloides: non-glandular trichomes multicellular uniseriate, whitish, frequent on petiol, midvein and edges of the foliar lamina, more rarely on foliar lamina.

Leaf scars elliptical or almost triangular, with angle rounded, $7 \mathrm{~mm}$ length, approximately $2 \mathrm{~cm}$ apart.

E. trigona (Plate I, E): Spines paired, $4 \mathrm{~mm}$ length, straight, divergent at an angle of 120 degrees, shining reddish-brown, become whitish-grey on old stems. The bases of the spines obovate, usually distinct, sometimes joined. On upper side rudimentary prickle.

Leaf scars bordered by bases of the spines, shape variable (circular, semicircular or polygonal), 2-3 mm length, whitish. 
E. umbellata (Plate II, A, G): non-glandular trichomes bulbose on edges of the lamina.

Leaf scars semilunar or elliptic, up to $1 \mathrm{~cm}$ length, alternately disposed, approximately $2.5 \mathrm{~cm}$ apart, obvious especially due to light brown colour on green surface of the photosynthetic stem. At the apex of the branches scars are $7 \mathrm{~mm}$ long, but they can get to $12 \mathrm{~cm}$ due to increase in thickness, in this case the shape is almost elliptic.

Most of the species mentioned in specialty literature are glabrous or, on the contrary, only have non-glandular trichomes [LUZ \& al. 2015; TALEBI \& al. 2017; ZAHRA \& al. 2014], as can be seen in the analysed taxa. In the case of E. pulcherrima the trichomes were only observed on the inner side, instead of both, as it appears in Flore des Mascareignes [RADCLIFE-SMITH, 1982].

The spiny structures are simple (E. stenoclada) or more complicated, a veritable armature (E. grandicornis, E. guentheri); in succulent species the "cow-horn" shape is frequent. All three types of spines mentioned by BROWN are present on our material, but for the type of spine represented by E. stenoclada, PEIRSON \& al. (2013) uses the expression "spine tipped branches". In addition, only RADCLIFE-SMITH used the term shields ("écusson" in French) in the description of E. milii and spinescent stipule ("stipules épineuses" in French) for the spines.

Spine shields are characteristic for Euphorbia species and may be isolated or joined, making a continuous edge. The colour is mostly light brown, but can become rusty-brown (E. ingens) or gray. At E. canariensis CARTER (2002) mentioned a blackish colour, never seen in our material.

Leaf scars vary from almost indistinguishable (punctiform, about $1 \mathrm{~mm}$ length e.g. E. tirucalli) to conspicuous, visible from a considerable distance (e.g. $12 \mathrm{~mm}$ length on an old stem of E. umbellata). The disposition toward the stem is different: at $E$. umbellata the scars are parallel with axes of stem/branches, at E. tirucalli they are perpendicular, and at $E$. myrsinites they form a 45 degrees angle. When it comes to species with tuberculous stems, the scars are disposed on the apex of the tubercles, like in the case of E. guentheri.

The leaf scars of E. canariensis bear in the centre five green formations which can be rudiments of leaves, as VIERA Y CLAVIJO (1942) suggest. In fact at this species the leaves are never seen and are not mentioned in any botanical description.

\section{Conclusions}

Trichomes, spines and leaf scars were treated as epidermal appendages first of all from the point of view of their disposition towards the surface of the stem, and secondly from the point of view of their provenance.

The epidermal appendages of aerial vegetative organs from the Euphorbia species present distinctive features valuable from a morphological point of view. The trichomes are only non-glandular and present at few species, especially non-succulent. The spines are variable in shape, colour and position and some of them are developed on a special structure, named spine shields. The leaf scars can be a valuable character, by their different shape and disposition around the stem surface.

The results of the observations are mainly available for cultivated items. 


\section{Notes on contributor}

Camelia IFRIM - is a botanist with a special interest in the study of the morpho-anatomy of exotic plants mainly from the Lamiaceae, Solanaceae and Euphorbiaceae families, as well as the study of the living collection in the greenhouses of the Botanical Garden Iassy.

\section{References}

ÁLVAREZ ESCOBAR A. \& RODRIGUEZ DELGADO O. 2014. Euphorbia canariensis. In: M. PARDO DE SANTAYANA, R. MORALES, L. ACEITUNO-MATA \& M. MOLINA (Eds). Inventario Español de los Conocimientos Tradicionales relativos a la Biodiversidad (IECTB). Madrid: Ministerio de Agricultura, Alimentación y Medio Ambiente. pp. 161-165.

ARCO AGUILAR M. J. DEL \& RODRÍGUEZ DELGADO O. 2018. Vegetation of the Canary Islands. Cham, Switzerland: Springer.

BEENTJE H. \& CHEE M. 2014. Flora of Tropical East Africa - Glossary (2003). CRC Press, 81 pp.

BERRY P. E., PEIRSON J. A., STEINMANN V. W., MORAWETZ J. J., RIINA R., YANG Y., GELTMAN D. \& CACHO N. I. 2016. Euphorbia. In: Flora of North America Editorial Committee (Eds). Flora of North America North of America. Volume 12. Oxford University Press, New York, New York. pp. 237-324.

BROWN N. E., HUTCHINSON J. \& PRAIN D. 1925. Euphorbiaceae. In: W. T. THISELTON-DYER (Ed). Flora Capensis, Vol 5, Part 2, Ashford, L. Reeve \& Co., 216 pp.

BRUYNS P. V., MAPAYA R. J. \& HEDDERSON T. 2006. A new subgeneric classification for Euphorbia (Euphorbiaceae) in southern Africa based on ITS and psbA-trnH sequence data. Taxon. 55(2): 397-420.

CARTER S. 1994. A Preliminary Classification of Euphorbia Subgenus Euphorbia. Ann. Miss. Bot. Gard. 81(2): 368-379.

CARTER S. 2002. Euphorbiaceae. In: U. EGGLI (Ed). Illustrated Handbook of Succulent Plants, Dicotyledons. Berlin, Heidelberg, New York: Springer. pp. 109-164.

CARTER S. \& LEACH L. C. 2001. Euphorbiaceae subfamily Euphorbioideae tribe Euphorbieae. In: G. V. Pope (ed). Flora Zambesiaca. Vol. 9(5), Royal Botanic Gardens, Kew, Richmond, pp. 339-465.

CARTER S. \& RADCLIFFE-SMITH A. 1988. Euphorbiaceae (Part 2). In: R. M. POLHILL (Ed). Flora of Tropical East Africa. Rotterdam: A. A. Balkema, pp. 409-564.

COATES PALGRAVE K. 2013. Trees of Southern Africa. New ed. revised and updated by M. Coates Palgrave. Cape Town: Struik Nature. eBook edition.

COURT D. 2000. Succulent flora of Southern Africa. CRC Press, pp. 109-139.

CREMERS G. 1978. Étude de deux Euphorbes de Madagascar: Euphorbia enterophora Drake et E. stenoclada Baillon. Adansonia, ser. 2. 7(3): 343-357.

DIAZ HERNANDEZ M. A. \& RODRIGUEZ DELGADO O. 1995. Contribucion al estudio taxonomico y descriptivo del cardon de canarias (Euphorbia canariensis). Rev. Acad. Canar. Cienc. 7(2, 3, 4): 93-110.

DORSEY B. L., HAEVERMANS T., AUBRIOT X., MORAWETZ J. J., RIINA R., STEINMANN V. W. \& BERRY P. E. 2013. Phylogenetics of Euphorbia subg. Euphorbia. Taxon. 62(2): 291-315.

DREZNER T. D. 2017. Variations in Saguaro Cactus (Carnegiea gigantea) spine length in wet and dry portions of their range. Madroño. 64(3): 93-98.

EVANS M., AUBRIOT X., HEARN D., LANCIAUX M., LAVERGNE S., CRUAUD C., LOWRY P. P. \& HAEVERMANS T. 2014. Insights on the evolution of plant succulence from a remarkable radiation in Madagascar (Euphorbia). Systematic Biology. 63(5): 697-711.

GALEŞ R. C. \& TOMA C. 2006. Histo-anatomical data of some Euphorbia species from the Romanian flora. An. Şt. Univ. “Al. I. Cuza” Iaşi, s. II a. Biol. veget. 52: 5-12.

GEBAUER R., ŘEPKA R., ŠMUDLA R., MAMOŇOVÁ M. \& ĎURKOVIČ J. 2016. Anatomical and morphological spine variation in Gymnocalycium kieslingii subsp. castaneum (Cactaceae). PhytoKey. 69: $1-15$.

GILBERT M. G. \& CARTER S. 1984. A Cactus-like Euphorbia from Ethiopia. Bradleya. 2(2): 9-14.

LUZ L. E.C., PALUDO K. S., SANTOS V. L.P., FRANCO C. R.C., KLEIN T., SILVA R. Z., BELTRAME F. L. \& BUDEL J. M. 2015. Cytotoxicity of latex and pharmacobotanical study of leaves and stem of Euphorbia umbellata (Janaúba). Revista Brasileira de Farmacognosia. 25: 344-352.

MAPAYA R. J. 2003. Molecular and morphological phylogenetic analyses of Euphorbia L. (Euphorbiaceae) with an emphasis on southern african representatives. Thesis, Department of Botany, University of Cape Town, South Africa.

NEUWINGER H. D. 1996. African Ethnobotany: Poisons and Drugs: Chemistry, Pharmacology, Toxicology. London: Chapman \& Hall. pp. 449-478. 
PEIRSON J. A., BRUYNS P. V., RIINA R., MORAWETZ J. J. \& BERRY P. E. 2013. A molecular phylogeny and classification of the largely succulent and mainly African Euphorbia subg. Athymalus (Euphorbiaceae). Taxon. 62(6): 1178-1199.

RABESANDRATANA R. 1984. Flora of the Malagasy Southwest. In: A. Jolly, P. Oberlé, R. Albignac (Eds). Key Environments - Madagascar. Oxford: Pergamon Press Ltd. pp. 55-74.

RADCLIFE-SMITH A. 1982. Euphorbia. In: J. Bosser et al. (Eds). Flore des Mascareignes. La Réunion, Maurice, Rodrigues. Mauritius: The Sugar industry research institute. pp. 94-95.

SCHMIDT E., LÖTTER M. \& MCCLELAND W. 2002. Trees and shrubs of Mpumalanga and Kruger National Park. Johannesburg: Jacana Media.

STEINMANN V. W. 2003. The submersion of Pedilanthus into Euphorbia (Euphorbiaceae). Acta Botanica Mexicana. 65: 45-50.

SWANEPOEL W. 2013. Euphorbia otjipembana subsp. okakoraensis (Euphorbiaceae), a new subspecies from the Kaokoveld, Namibia, with an amplified description of Euphorbia otjipembana. Phytotaxa. 117(2): 5157.

TALEBI S. M., NOORI M. \& NANIZ H. A. 2017. A study of epidermal leaf anatomy of 18 Euphorbia taxa from Kerman Province, Iran. Biologija. 63(2): 126-133.

THAKUR H. A. \& PATIL D. A. 2012. The family Euphorbiaceae: Anatomical conspectus. World Journal of Science and Technology. 2(6): 51-57.

VIERA Y CLAVIJO JOSÉ DE. 1942. Diccionario de Historia Natural de las Islas Canarias o Índice alfabetico decriptivo de sus tres reinos animal, vegetal y mineral. Tomo I. Santa Cruz de Tenerife: Valentin. pp. 171-173.

ZAHRA N. B., AHMAD M., SHINWARI Z. K., ZAFAR M. \& SULTANA S. 2014. Systematic significance of anatomical characterization in some euphorbiaceous species. Pak. J. Bot. 46(5): 1653-1661.

*** JSTOR Global Plants. 2013. http://plants.jstor.org/ [accessed 1 June 2012].

How to cite this article:

IFRIM C. 2018. Studies on epidermal appendages from vegetative organs at Euphorbia species cultivated in Botanical Garden Iassy. J. Plant Develop. 25: 15-24. https://doi.org/10.33628/jpd.2018.25.1.15

\section{Explanation of the plates}

Plate I (scale bars $=1 \mathrm{~cm}$ )

A. Euphorbia grandicornis - spines shields with spines on branche: 1 - spine shields, 2 - spines, 3 prickles, 4 - leaf scar

B. E. ramipressa - spines shields with spines on tertiary branch

C. E. guentheri - clusters of spines and leaf scar with a drop of latex on stem

D. E. canariensis - spines shields with spines on secondary branch

E. E. trigona - spines and leaf scar on secondary branch

F. E. millii - tertiary branch with spines and leaf scar

G. E. stenoclada - spine on terminal branch

H. E. ferox - spine on stem

I. E. ramipressa - old stem with subcontinuous lines of spine shields and spines

J. K. E. ingens - stem with spines on rusty, respectively grey spine shields

Plate II (scale bars $=1 \mathrm{~cm}$ )

A. E. umbellata - trichome on margin of the leaf $(700 \mathrm{x})$

B. E. cotinifolia - trichomes on petiol of juvenile leaf $(350 \mathrm{x})$

C. E. leuconeura - cartilaginous stipules on edge of branche

D. E. leuconeura - cartilaginous stipules with bristles on edge of branche $(100 \mathrm{x})$

E. E. milii - clavate and cylindrical trichomes on surface of branche $(700 \mathrm{x})$

F. E. tirucalli - leaf scar with stipular remnants on terminal branch

G. E. umbellata - leaf scar on tertiary branch

H. E. milii - leaf scar on tertiary branch

I. E. leuconeura - leaf scar on secondary branch

J. E. pteroneura - leaf scar on secondary branch 


\section{Plate I}
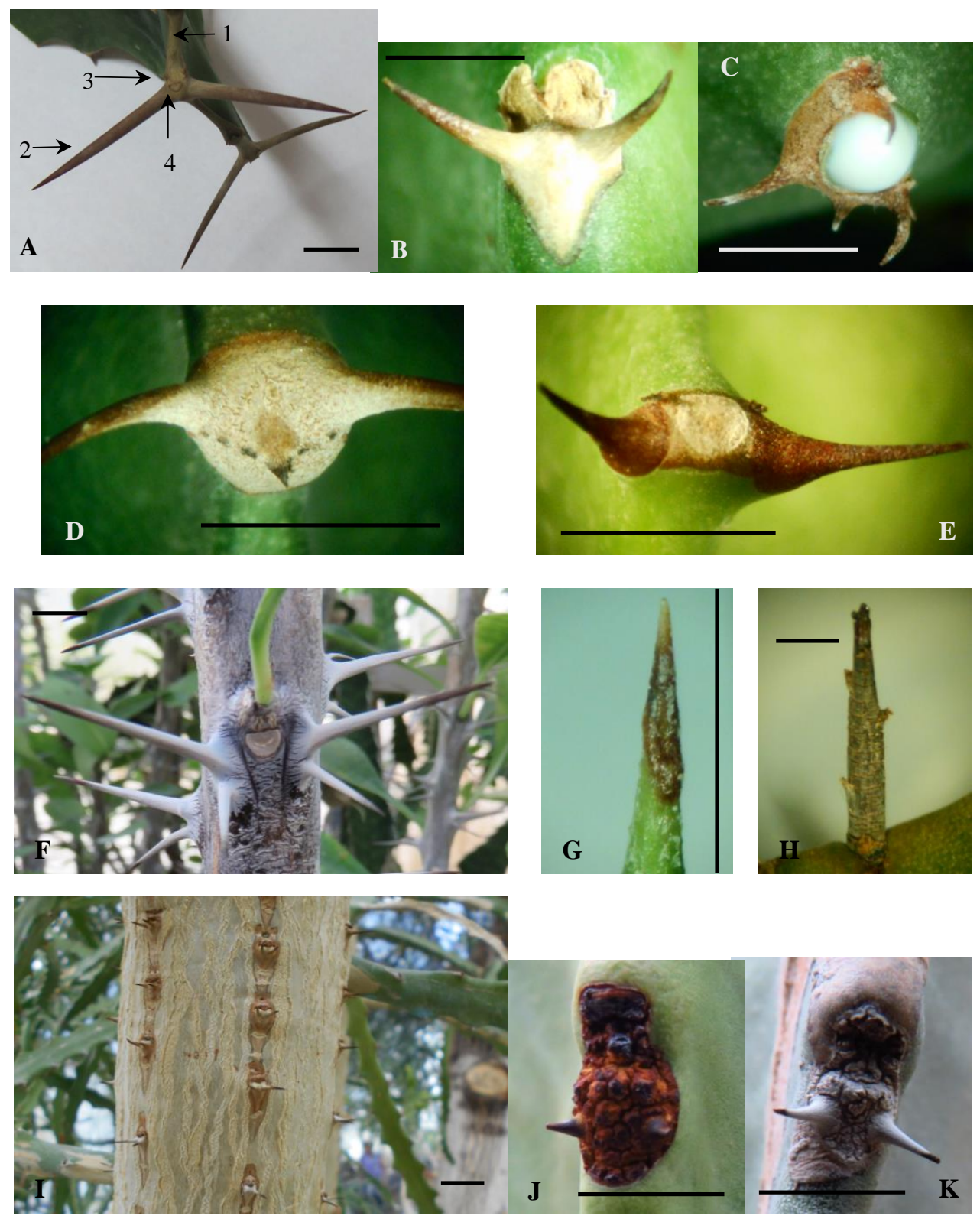
Plate II
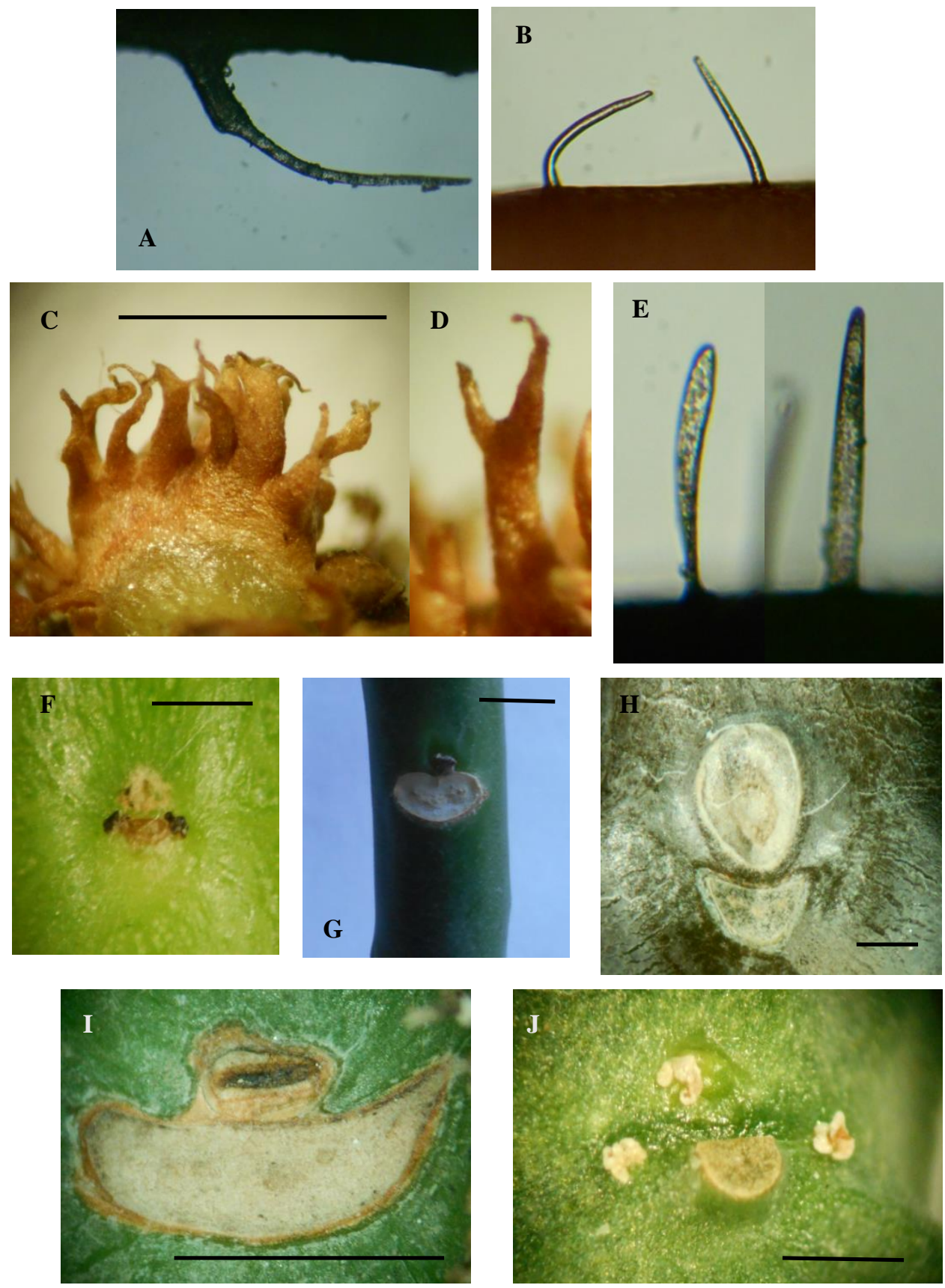